\title{
Translating the Gospel According to John: Dimensions of Space and Culture
}

SARAH MARIAM RoY

\begin{abstract}
The translation of the Bible into English or any other languages call for a translation of the original space and culture which gave way to the production of the text. By merely translating the linguistic elements of the text, there occurs the drastic loosening of the text. Ernst August Gutt asserts that the stimulus i. e. the translated text, placed in its cognitive environment produces the original interpretation. While comparing, it is essential to keep Gutt's perspective of original context in mind. To Gutt, a translation is successful only when the original context is made clear. It can be by means of contextual effects or communicative clues or explicating the implicit information; but it is against the idea that the translation must be modernized.
\end{abstract}

Keywords: Translation, Culture, Relevance Theory, Secondary Communication, Cognitive Process.

\section{Introduction}

Culture and communication are two sides of the same coin and humanity is intricately involved in the making and sharing of the symbols. Communication occurs when these symbols interact. Culture is that space or environment for communication to take place. Hence this environment, as Bluck states, "as fragile as the natural world. Its preservation and stewardship is an ecological issue" (Bluck 1989: 5). The translation of the Bible into English or any other languages call for a translation of the original space and culture which gave way to the production of the text. By merely translating the 
linguistic elements of the text, there occurs the drastic loosening of the text. Ernst August Gutt asserts that the stimulus i. e. the translated text, placed in its cognitive environment produces the original interpretation.

Jesus used both the language and culture of the people to be able to communicate with them. He lived in their Jewish, firstcentury culture and communicated in the context of that culture so that people could understand him. For example, Jesus spoke about vineyards, fishing, shepherds, Roman coins and Old Testament passages as these were familiar to his audience and hence could be easily understood. It is believed by Bible Translation practitioners: "the drive for vernacular translation is the essential belief that no two people or cultures are the same. Hence without people praising God in the ways that are particular to their language and culture, it remains a loss and the wonder of that special praise will be wanting," (Hill and Gutt 2011: 170-172).

During the period of Christ on earth, Latin, Greek, Aramaic and Hebrew were in use for different purposes. While Latin was the prestigious language of the colonial authorities; Greek was the language of education, communication and trade; Aramaic was the language used in the homes of the Jews and Hebrew was the language of the Jewish Scriptures, temple worship and religious studies. Scholars believe Jesus used Aramaic which was spoken at home. By the time the Gospels were written, the intended audience included many people who did not speak Aramaic or read Hebrew, so the Gospel writers translated what Jesus said into Greek. In fact, the Old Testament had already been translated from Hebrew into Greek in the centuries before Christ, so that Jews living in Greek-speaking lands could understand it. There were two varieties of Greek: the Gospel writers could choose from sophisticated Greek used in the literature and common Greek 
spoken by ordinary people. They chose to write in koine Greek/common Greek (Hill and Gutt 2011: 146-147).

Considering translation within the pragmatic frame work, the communication in translation has the author of the source text and the translator as the parties of the first round of communication and the translator and the recipient of the translated text as the parties of the second round communication (Hu 2009: 14).

The stories of Jesus' life were called among Christians as Gospels. Thus, they were introducing a new genre of writing for which no current category would suffice. It was not merely a biography or chronicle of his miracles; but preaching designed to retell the account of Christ's life, ministry, death and resurrection: "we place such a high value on these four books of the Bible because they contain the essence of the saving events which form the bedrock of the apostolic gospel. These books are historical in the way they root Jesus' life-story in the world of first-century Judaism and Graeco-Roman society" (Martin 1997: 27).

In a contemporary world that tends to become more global, it is not clear any more how metaphorical the extension of language to the whole world of communication still is. Anyway we may suppose that the kind of strategies, norms and conflicts that can be observed empirically in the case of translation appear in general. And if this view is correct, the question of research on translation is directly linked with the problem of metaphor. Is it a metaphor at all to assume that translation is a matter of communication and not just of language? (Lambert 1997: 64).

\section{Relevance Theory in Translation}

The Relevance theory was originally forwarded by Wilson and Sperber in the study of communication. It was later adopted by 
Ernst-August Gutt in providing a theory for translation. Following that translations carry the inherent function of communicating, the theory borrows this notion from communication and seeks to bring a framework for translation. The Relevance Theory claims "human communication crucially creates an expectation of optimal relevance, that is, an expectation on the part of the hearer that his attempt at interpretation will yield adequate contextual effects at minimal processing cost” (Malina 2001: 50).

In his article, "Aspects of Cultural Literacy Relevant to Bible Translation," Gutt examines the extent and nature of biblical literacy, needed for the successful comprehension of a sample text Luke 10:13-14. This is possible with the help of conceptual tools provided by Relevance Theory. The first task is to systematically identifying mismatches in background knowledge between original and receptor audience. He emphasizes the need for providing more background material to the audience for satisfactory comprehension. The starting points for the interpretation would be the following: the initial context (i.e. what has just been communicated before); the stimulus (i.e. the concepts evoked by the text), the extended context (which will make accessible the encyclopaedic entries of those concepts, containing further background knowledge and may also lead to more concepts and their encyclopaedic entries) (Gutt 2006: 6-7). This information is ordered based on the degrees of accessibility. Based on the availability of accessible information, the initial context is the most accessible information which is followed by the encyclopaedic information which is directly associated with the concepts in the stimulus; it can also be supplemented with further extensions of the context. According to Gutt, the words are only the "tip of the iceberg" (an analogy from Hirsch) and hence more than eighty-five percent or more of its mass lies below the surface. This is in stark contrast to the idea that 
implicit information may only be small pieces of information. Gutt also points out that the bulk of the iceberg is hidden from view which is similar to the fact that the bulks of the interpretive processes of the mind are below the level of consciousness and not open to introspection. For Gutt, RT (Relevance Theory) tools should be used to investigate the implicit information (Gutt 2006: 7).

Based on the explication of the implicit meaning done by Gutt, this research aims to compare the three translations with this frame in mind. While comparing, it is essential to keep Gutt's perspective of original context in mind. To Gutt, a translation is successful only when the original context is made clear. It can be by means of contextual effects or communicative clues or explicating the implicit information; but it is against the idea that the translation must be modernized.

\section{The Gospel According to John and the Johannine Audience}

The text was produced for a community with the intention to produce new communities and is now read by new communities in the translated form. When a text within a community crosses borders: it faces challenges in expression. The transplanted group of New Testament writers can be wholly understood only when we pay careful attention to the cultural system that has created them. Their cultural story, cultural cues, cultural script and its study using atlases and encyclopaedia can help us identify a concrete environment of the original text (Malina 2001: 9).

As the author, John was of Jewish origin, he held a natural affinity for Jewish sources such as the Old Testament, the Qumran writings and the writings of the Jewish rabbis. Their use and influence is evident throughout the text. The use of unknown concepts is minimal in the Gospel given the assumption that he was writing for Johannine community. One 
of the major problems identified in the translation of the Bible is its transplantation of the text in a different time and cultural setting. This rupture with a different age and a different civilization is but complex to say the least. As the original text was written for a Johannine community; an understanding of the cognitive environment of the same community is but essential in understanding the Gospel.

The Apostle John is usually credited with the authorship of the fourth Gospel. John's Gospel is generally considered to be the last of the four canonical Gospels in the New Testament. The majority of scholars date the Gospel in the period AD 90-100, though some have dated it much earlier (Keener 2003: 27). The Gospel was written in a pluralistic context where there was a sufficient intermingling of ideas and philosophies. The several strands of thought that were current in the late first century include Palestinian Jewish thought, Hellenistic thought, Christian thought and incipient Gnostic thought (Thompson 2006: 190). All of these have contributed to shaping John. Even though John regularly observes Christ as the fulfilment of Old Testament prophesies; he does not refrain from borrowing contemporary concepts based on Hellenistic influences and uses Jewish imagery (Tan 2006: 167-170).

The term 'logos,' appears several times in The Prologue in John's Gospel. It is the focal point of the entire Gospel. Hence a study of the word and its origin is necessary for communicating via translation. The Gospel of John is one of the three block of writings in the New Testament which have been associated with possible indebtedness to Philo, but however according to Ferguson the logos in the Prologue goes beyond all that Philo had postulated; there is no need of considering the dependence of Philo's philosophical consideration (Ferguson 2003: 90). 
The Gospel has a theological message which is grounded in historical reality and therefore presents an association between the historical Jesus and the Divine form. Hence there is an interaction of History and interpretation; biography and theology and hence referred to as the simplest but the most profound and the title of "the crown of the scriptures" (Howard 1952: 437).

There is evidence to suggest the movement of a group of followers from Palestine to Asia minor during the AD 60-70 and is now referred to as the Johannine community (Anderson 2017: 3). It is central to understand the background of such a community in which the text was written; as obviously the author shares the same language, culture and social system to communicate his intention. Thus for a clear understanding of the text, the cognitive environment of the community is sought to be undertaken briefly.

\section{Context of Production}

The study of literature around the world is always accompanied by researching the historical and cultural backgrounds that has contributed to the formation of the work. But seldom is a discussion raised on how the contexts of production are responsible for the origin of the literature itself. Hence it has been rightly observed:

... literature regularly asks questions about history and about the processes by which historical knowledge and understanding are shaped. What is somewhat less common is to see historical questions asked of literature - questions, for example, such as how and why particular types of literature should emerge from particular sets of historical circumstances (Poplawski 2017: 1). 
In the same line, translation as an activity in literature is also affected by the context surrounding it; a study into it will reveal the marked interrelatedness of the context and the production of translation.

Followers of Christ, started facing persecution which grew from the hostility of the Jews and in such a context, the document is expected to have been a reminder of Christ as God and God's love for the world and the promise of eternal life. Its primary aim is to produce faith in Jesus Christ as Son of God: "But these are written that you may believe that Jesus is the Christ, the Son of God, and that believing you may have life in His name" (John 20:21 New King James Version - NKJV).

The author of the Gospel refers to an individual 'saw,' 'testifies' and 'wrote' the events, and the Johannine community attests that his testimony is true (John 19:35, 21, 24). It is probable that this individual was the beloved discipleJohn who had compiled his preaching materials. The Johannine community he founded may also have to put them together in the course of their worship, teaching and missionary preaching. John could have used this collection as his primary source. It is not improbable that he had been in contact with the Synoptic gospels that were already in circulation in the contemporary period. Similarly, the dominant motifs of John can be found to have an increasing similarity with the Pauline teachings; such as righteousness, Son of Man, the Passover Lamb, Wisdom and 'abiding in' (Kanagaraj and Kemp 2002: 21-23).

Even though the John regularly observes Christ as the fulfilment of Old Testament prophesies; he does not refrain from borrowing contemporary concepts based on Hellenistic influences. The Prologue successfully introduces the major themes such as the Word, light, life, witness, world, believing, seeing glory and God's self-revelation in the Logos incarnate. 
There is contention regarding the aspects of the Prologue as the presentation of Christianity in a Hellenized form but the teachings of Christ were written in the Greek language for a common audience of both Greeks and Jews. Hence depending only on the Hellenistic School of thought is not a matter of necessity. Notwithstanding the concept of logos though having various inferences based on the situation it is placed; can be deduced using the principle of Relevance which is the interpretation using minimum processing effort in the first step and continue till adequate cognitive benefits are supplied.

In the beginning was the Word, and the Word was with God, and the Word was God. He was in the beginning with God. All things were made through Him, and without Him nothing was made that were made. In Him was life, and the life was the light of men. And the light shines in the darkness, and the darkness did not comprehend it (John 1: 1-5 NKJV).

By means of the prologue the author attempts to help Jews, Greeks and other religious philosophers to understand God in His relationship with human beings. The absolute use of the term logos and the use of terms phrases as grace upon grace and of his fullness provide us evidence that though they do not recur in other parts of the following text; the source of the Prologue has been drawn by the author from the Old Testament and the cultural environment of the Johannine community to form a preamble to his work.

Unlike the other Gospels, John's gospel does not begin with the historical Jesus; instead he approaches the person of Jesus with the logos i.e. Word and identifies it with the person of Jesus only by the end of the Prologue. The Gospel presents logos as the eternal, pre-existent and now incarnate Word. By communicating that Jesus is the only Son of God the Father and that he was there from the beginning the Prologue deals with the person of Jesus addressing the notion of salvation. 
The Prologue introduces many of the major themes developed later in the Gospel of Jesus: light, life, truth, salvation and the world's rejection of Jesus. Hence it is essential to study the exegesis and etymology of the word logos as it would have been received by the original/earliest readers. The Hellenistic roots have the term logos for the Stoics meant the principle of divine reason which makes natural creation to grow and controls the stars and seasons. The Hellenistic Jewish roots leads us to a Jewish philosopher named Philo from Alexandria has contributed to the understanding of the logos at length. But the difference between Philo's conceptions of logos exists as it does not conceive of it as a person existing before creation. There is close parallel between the OT, the Wisdom tradition and Philo, nonetheless. Jewish roots in logos directly echo the nature of enarche, in the Prologue; the Jewish mind is recalled to the creation account in Genesis. The notion of the creative activity of God done by the power of his Word is present in the Jewish wisdom literature such as in Proverbs 8 and Wisdom 18:15.16. The Hebrew equivalent dabar is used in the context of creation to bring light to a dark sphere and the creation of everything. The Aramaic equivalent of logos is memra is used in the Targums for God and his activities; it is also used as a synonym for God himself and His powerful acts. The recently discovered Dead Sea scrolls also provide the Jewish milieu of a parallel creation account (Fries 1997: 1117).

John writes primarily for the audience just before his eyes; but also as a text for succeeding generations. Thus he draws from the immediate surroundings- the use of Greek language which had by now become the mother tongue of Jews as well. The encounter with the outside world for the community was obviously an issue of concern; the details of crucification and resurrection and the miracles must have been parts of oral history; but the call for discipleship exists "even to the remotest part of the earth"(Acts 1.8) and to the "end of the 
ages" (Matthew 28.20). This aspect of primary and secondary audience is essential for communication in translation. The secondary audience could be the succeeding generations of the Johannine community. Our primary aim is to identify the struggle faced by the translator given that considering translation within the pragmatic frame work, the communication in translation has the author of the source text and the translator, as the parties of the first round of communication; and the translator and the recipient of the translated text, as the parties of the second round communication ( $\mathrm{Hu}$ 2009: 4). The translator struggles to perform the task of the communicator.

The textual narrative was evidently selected and recounted with readers in mind with the use of the personal pronoun 'you' in $(20.30,31)$ thus making it clear that the Fourth Gospel is "an exercise in communication; of a message intended to shape the stance of its readers". The Hellenistic and Jewish backgrounds, serve as the cognitive environment of John. At one end of the reading spectrum are "the contemporary readers that eclectic group comprised of all who read the ... The problem is that contemporary readers do not understand John's Gospel in the same way" (Kroester 1996: 5).

The opening words of Genesis and John are enough to draw a close relation in the minds of the earliest readers. In their cognitive process; the creation account was already present with the creative act of God using his words alone. This cognitive environment is brought to mind before entering the discourse (Anderson 2017).

Philip found Nathanael and said to him, "We have found Him of whom Moses in the law, and also the prophets, wrote-Jesus of Nazareth, the son of Joseph."46 And Nathanael said to him, "Can anything 
Sarah Mariam Roy

good come out of Nazareth?" Philip said to him, "Come and see" (John 1: 46 NKJV).

The first century Mediterranean world had a collective culture wherein social groups, family, neighbourhood, village or a region carried a collective honour to which the members participated. This can be seen in contrast to the individualism of the modern world (Malina 2001: 65).

The next day John saw Jesus coming toward him and said, "Behold! The Lamb of God who takes away the sin of the world! (John 1: 29 NKJV).

John the Baptist refers to Jesus as "the Lamb of God". It was the Levitical code for the Jews that on the Day of Atonement, a goat was sacrificed by the high priest and another goat was also taken as a scapegoat. In Leviticus 16:22, "The goat shall bear on itself all their iniquities to an uninhabited land; and he shall release the goat in the wilderness" (NKJV, 2006). During the days of Moses it was customary that the scapegoat to be left loose in the wilderness but in order to prevent its return it was customary among the Jews to push over the scapegoat to the height of a mountain with the effect of being killed (Wight 1953: 168). Hence the picture of a scapegoat is contrasted with Jesus when the title "Lamb of God" is given. The absence of such a rich dimension of meaning; the sin bearing role of the lamb, the priestly sacrifice, the Passover lamb, the Passion lamb in the context of a new redemption (Keener 2003: 454) which takes its roots in the culture and times of its origin is lost in translation.

\begin{tabular}{|l|l|l|}
\hline $\begin{array}{l}\text { Figurative } \\
\text { Sayings }\end{array}$ & $\begin{array}{l}\text { John } \\
\text { References }\end{array}$ & Old Testament References \\
\hline $\begin{array}{l}\text { I am the bread } \\
\text { of life }\end{array}$ & $6.35,48,51$ & $\begin{array}{l}\text { Exod 16; Num 11.6-9; Ps 78.24; } \\
\text { Isa 55.1-3; Neh 9.15 }\end{array}$ \\
\hline $\begin{array}{l}\text { I am the light of } \\
\text { the world }\end{array}$ & $8.12,9.5$ & $\begin{array}{l}\text { Exod 13.21-22; Isa 42.6-7; Ps } \\
97.4\end{array}$ \\
\hline
\end{tabular}


Translating the Gospel According to John:...

\begin{tabular}{|l|l|l|}
\hline $\begin{array}{l}\text { I am the door of } \\
\text { the sheep }\end{array}$ & $10.7,9$ & \\
\hline $\begin{array}{l}\text { I am the good } \\
\text { shepherd }\end{array}$ & $10.11,14$ & $\begin{array}{l}\text { Ezek 34.1-41; Gen 48.15; 49.24; } \\
\text { Ps 23.1-4; 80.1; 100.3-4; Micah } \\
7.14\end{array}$ \\
\hline $\begin{array}{l}\text { I am the } \\
\text { resurrection and } \\
\text { the life }\end{array}$ & 11.25 & Dan 12.2; Ps 56.13;2 \\
\hline $\begin{array}{l}\text { I am the way, } \\
\text { the truth and the } \\
\text { life }\end{array}$ & 14.6 & $\begin{array}{l}\text { Exod 33.13; Ps 25.4; 27.11; } \\
86.11 ; 119.59 ; \text { Isa 40.3; 62.10, Ps } \\
25.5 ; 43.3 ; 86.11 ; 119.160 ; \text { Isa } \\
45.19\end{array}$ \\
\hline $\begin{array}{l}\text { I am the true } \\
\text { vine }\end{array}$ & 15.1 & $\begin{array}{l}\text { Isa 5.1-7; Ps 80.9-17; Jer 2.21; } \\
\text { Ezek 17.5-10 }\end{array}$ \\
\hline
\end{tabular}

Table 1: Figurative sayings in John

In John 2.22, it is given to understand that the synagogue met regularly to read from the Old Testament which is ascribed to as the 'Law' in OT and 'Scripture' in NT- "Then Ezra the priest brought the law before the assembly of men, women and all who could listen with understanding ... They read from the book, from the law of God, translating to give the sense so that they understood the reading" (Neh. 8.3, 8). Such information in Table 4.2 and 4.3 are already available in their cognitive environment- through the teaching of law in the community's practices. When the figurative sayings and the themes spoken by Jesus are read together with this context, the inferring of interpretation is possible. It is not so for the secondary audience such as the present day audience of the Bible.

\begin{tabular}{|l|l|l|}
\hline Theme & John & Isaiah \\
\hline $\begin{array}{l}\text { The shepherd and the } \\
\text { sheep }\end{array}$ & $10.1-21$ & 40.11 \\
\hline Water for the thirsty & $4.13-14$ & $\begin{array}{l}41.18 ; 44.3 ; 48.21 ; \\
49.10\end{array}$ \\
\hline Food for the hungry & 6.35 & $55.1 ; 49.10$ \\
\hline Guidance & 14.16 & $42.16 ; 48.17$ \\
\hline The divine comforter & 14.16 & 51.12 \\
\hline The gift of the Spirit & $14.26 ; 15.26 ; 16.13$ & 59.21 \\
\hline
\end{tabular}


Sarah Mariam Roy

\begin{tabular}{|l|l|l|}
\hline Worldwide salvation & $4.21-24 ; 10.16$ & $\begin{array}{l}43.19 ; 45.22 ; 49.12 ; \\
56.78 ; 60.3\end{array}$ \\
\hline Freedom from flesh & 14.1 & $41.1 ; 51.7$ \\
\hline Sight for the Word & 9.39 & $35.5 ; 42.7$ \\
\hline Liberty for the bound & 8.36 & 61.1 \\
\hline Divine teaching & $14.10 ; 17.6-8$ & $50.4-5$ \\
\hline
\end{tabular}

Table 2: The Jewish Messianic cultural image as the cognitive environment in John

The wedding feast in John 2, was in the Mediterranean world associated with a sense of honour and stigma in the western or modern culture of the audiences of the translated text of New International Version, the Message and other modern English versions. The wedding banquet was presided over by the ruler of the feast. It was considered to be his duty to take care of the preparations and during the feasts he would oversee the supply of food to the guests and that nothing was lacking. He would give instructions to the servants in carrying out all the needed arrangements (Wight 1953: 134).

Now the Passover of the Jews was at hand and Jesus went up to Jerusalem (John 2: 13 NKJV).

Passover is an eight day festival commemorating the Hebrew escape from bondage in Egypt. It also marks the coming of spring and the rebirth of a Hebrew people. The First Passover took place during the last of the plaques which God had sent in order to free the Israelites from the Pharaoh of Egypt. This last plaque of killing the firstborn of every household in Egypt does not stand valid for the Israelites who had marked their doorpost with blood and had eaten unleavened bread. During the Passover, it was customary to offer calves in the calving season and grains or first grains during the harvest season at the Temple (Riedel, Tracy and Maskowitz 1979: 70).

The historical setting for the New Testament and early Christianity has been described as a series of concentric circles; of which the Roman world provided the outer circle: 
the governmental, legal and the economic context; the Greek world provided the cultural, educational and philosophical context and the Jewish world was the matrix of early Christianity, providing the immediate religions context. Thus Palestine was already Hellenised and such was the setting of Jesus life and ministry (Ferguson 2003: 1).

The Jews in the Gospel of John is a categorization which is repeatedly mentioned in the Gospel. Though there have been varying debates regarding the intended thought of the author; we must take into consideration that the original audience of the Gospel were in fact excluded from the synagogue and felt cut off from their Jewish heritage. Hence John, the author can be taken to positively asserting the groups identity as Israel while at the same time conceding to the opponents in an ironic way to mean that the Johannine community may claim to be Jews and really are (Keener 2003: 227).

Nathanael said to Him, "How do you know me?"Jesus answered and said to him, "Before Philip called you, when you were under the fig tree, I saw you. (John 1: 48 NKJV)

Nathaniel is mentioned as sitting under the fig tree; which was usually considered to be an activity done when one is resting and meditating the Scripture. The fig tree is one of the seven foods that were the "glory of Israel" and an important article for trade. It in Jewish culture stood for a well-known image for the coming of the Messiah and a time of peace as that of each man sitting under his own vine and fig tree and as symbols of prosperity (Riedel, Tracy and Maskowitz 1979: 112).

In John, the message is grounded in historical reality and therefore presents an association between the historical Jesus and the Divine form. There is an interaction of History and interpretation; biography and theology and hence referred to as the simplest but the most profound and the title of "the crown 
of the scriptures" (Howard 1952: 437). There is evidence to suggest the movement of a group of followers from Palestine to Asia minor during AD 60-70 and is now referred to as the Johannine community. Relevance Theory considers the Johannine community as the primary audience and the present audience of the translated text as the English audience i.e. the secondary audience.

Thus the interpretation of a text is a cognitive process involving the stimuli or concept with the contextual information and its translation is a cognition-based communication of the originally derived interpretation. This implies in relevance theoretic terms the activity in translation has the following procedures:

1. The identification of the stimuli by the translator

2. Identifying of the contextual information required for the stimuli to be processed

3. Identifying the cognitive process for interpretation i.e. the interaction between stimuli and the cognitive environment.

4. Translation of the text should be accompanied with a translation of contextual material for the secondary audience.

5. The inference of interpretation is usually done, can be done by processing the contextual information until adequate cognitive benefits are realised.

\section{Conclusion}

In secondary communication situations, the communicative event is reduplicated. Hence it is considered as an enabling act; ...translation can be seen as enabling - often for the first time - original access to a different world of knowledge, to different traditions and ideas that would otherwise have been locked away behind a language barrier. From this perspective, translation has often been described as a builder of bridges, an 
extender of horizons, providing recipients with an important service and enabling them to move beyond the borders of the world staked out by their own language (House 2015: 3).

Johannine audience and their familiarity with the Jewish laws prompt us to consider the Lamb of God in perspective as an appropriate and communicative title for Jesus. Jerusalem festivals, Jewish symbols written in the Greek tongue are themselves a translation of space and a struggle for communication. Their translation into English especially in today's modern world calls for the identification and prioritization of space and time of the original text.

...to realise that in reading the Bible in English (or even Greek), we are in fact listening to the words of a transplanted group of foreigners. It takes only the ability to read to find out what they mean. If meaning derives from a social system, while wording (e.g. Speaking or writing) simply embodies meaning from the social system, then any adequate understanding of the Bible requires some understanding of the social system embodied in the words that make up scripture... (Bluck 1989: 2).

\section{References}

Alexander, L. 2006. What is a Gospel? In S. C. Barton (Ed.). The Cambridge Companion to the Gospels. New York: CUP. 13-33

ANDERSON, P. 2017. Johannine Community. Online: <https://www.bibleodyssey.org:443/en/people/relatedarticles/johannine-community>

BAKER, M. 1998. The Routledge Encyclopedia of Translation Studies. London: Routledge.

BluCK, J. 1989. Christian Communication Reconsidered. Geneva: WCC. 
Brown, R. E. 1988. The Gospel and Epistles of John: A Concise Commentary. Minnesota: The Liturgical Press.

BrucE, F. 1984. The Books and the Parchments: How We Got Our English Bible. New Jersey: F. H. Revell.

Clark, D. J. 2015. Translation as Reincarnation? The Bible Translator 66 (2). 117-128.

COMfort, P. W. 2003. Texts and Manuscripts of the New Testament. In P. W. Comfort (ed.), The Origin of the Bible. Illinois: Tyndale. 185-215.

CulPePPER, A. R. 1998. The Gospel and Letters of John. Nashville: Abingdon.

FERGUSON, E. 2003. Backgrounds of Early Christianity (3rd ed.). Michigan: Eerdmans.

FRIES, G. 1997. Logos. In C. Brown (ed.), New International Dictionary of New Testament Theology Vol. III. Michigan: Zondervan. 1081-1119.

GUTHRIE, D. 1990. New Testament Introduction. Illinois: IVP. GuTT, E. A. 1990. A Theoretical Account of Translation Without a Translation Theory. Target: International Journal of Translation Studies 2 (2). 135-164.

GuTT, E. A. 2006. Aspects of "Cultural Literacy" Relevant to Bible Translation. Journal of Translation. 4-12.

GuTt, E. A. 2000. Translation and Relevance: Cognition and Context. New York: Routledge.

HiLl, H.; and E. A. GuTT. 2011. Bible Translation Basics: Communicating Scripture in a Relevant Way (Kindle ed.). Texas: SIL International.

House, J. 2015. Translation Theory and Translation Quality Assesment: Past and Present. New York: Routledge.

HowARD, W. F. 1952. Introduction. In The Interpreter's Bible Vol. VIII. Nashville: Abingdon Cokesbury. 437-462.

Hu, R. June 2009. Explorations into the Essence of EnglishChinese and Chinese-English Translation based on Relevance Theory.

Online: 
Translating the Gospel According to John:...

http://www.ccsenet.org/journal/index.php/elt/article/view/2 356

Kanagaraj, J. J. 2005. The Gospel of John: A Commentary. Secundarabad: OM.

KANAGARAJ, J. J.; and I. S. KeMP. 2002. The Gospel According to John. Singapore: Asia Theological Association.

KeEner, C. S. 2003. The Gospel of John: A Commentary Vol. 1. Massachusetts: Hendrickson Publishers.

KING, P. 2005. Translating "Messiah," "Christ," and "Lamb of God". Journal of Translation. 1-27.

Kostenberger, A. J. 2003. Translating John's Gospel:

Challenges and Opportunities. In G. G. Voth (ed.). The Challenge of Bible Translation. Michigan: Zondervan. 347364.

Kroester, C. R. 1996. The Spectrum of Johannine Readers. In F. F. Segovia (ed.). What is John? Readers and Readings of the Fourth Gospel. Georgia: Society of Biblical Literature. 5-20.

LAMBERT, J. 1997. Problems and Challenges of Translation in an Age of New Media and Competing Models. In P. A. Soukup \& R. Hodgson (Eds.). From One Medium to Another: Basic Issues for Communicating the Scripture in New Media. Kansas: Sheed \& Ward. 51-66.

Laughlin, J. C. 2006. Fifty Major Cities of the Bible: From Dan to Beer Sheba. London: Routledge.

MalinA, B. J. 2001. The New Testament World: Insights from Cultural Anthropology (3rd ed.). Louisville: Westminister John Knox Press.

MARTIN, R. P. 1975. New Testament Foundations: A Guide for Christian Students 1. Michigan: Eerdmans.

RiEDEL, E; T. TRACY; and B. D. MaskowiTZ,. 1979. The Book of the Bible. New York: William Morrow and Company. 
Sarah Mariam Roy

SPERBER, D; and D. WILSON. 2004. Relevance Theory. In L. Horn \& G. Ward (eds.). Handbook of Pragmatics. Blackwell. 607-632.

StRauss, M. 2010. Gospels. In G. T. Kurian \& J. D. III (eds.).

The Encyclopedia of Christian Literature. Maryland:

Scarecrow Press. 82-86.

TAN, Y. H. 2006. The Johannine Community Caught in Two

Worlds. In F. L. Jr. \& T. Thatcher (eds.), New Currents

Through John: A Global Perspective. Atlanta: Society of Biblical Literature. 167-182.

The Holy Bible: New King James Version. 2006. Nashville:

Thomas Nelson.

Thompson, M. M. 2006. The Gospel According to John. In S.

C. Barton (ed.). The Cambridge Companion to Gospels.

Cambridge: CUP. 182-200.

Van Der Henst, J. B.; and D. SPerber. 2004. Testing the Cognitive and Communicative Principles of Relevance. In

I. Noveck \& D. Sperber (eds.). Experimental Pragmatics.

New York: Palgrave. 229-279.

WALKER, L. 2003. Biblical Languages. In P. W. Comfort (ed.).

The Origin of the Bible. Illlinois: Tyndale. 217-238.

Wight, F. H. 1953. Manners and Customs of Bible Lands. Chicago: Moody Press. 